\title{
The relationship between hydrogen and its application in wind energy: A systematic review
}

\section{Matheus Eurico Soares de Noronha ${ }^{1}$ and André Themoteo da Silva Melo ${ }^{2}$}

${ }^{1}$ Escola Superior de Propaganda e Marketing. Rua Dr. Álvaro Alvim, 123. Vila Mariana. São Paulo-SP, Brasil (CEP 04018-010). E-mail matheus@abeeolica.org.br. ${ }^{2}$ Universidade Federal do ABC. Rua Abolição, S/No. Vila São Pedro. Santo André-SP, Brasil (CEP 09210-180).

\begin{abstract}
The aim of this study was to map papers about the use of hydrogen as a fuel and its association with wind energy under siege in two databases (Web of Science and Scopus) to provide insights about this topic and verify its current context. This study was a systematic literature review and content analysis of 87 papers from Web of Science and Scopus database. The papers were analyzed from descriptive, bibliographic, methodologic, results and citation characteristics. The publications about this theme have been mostly developed using mixed research models (quantitative and qualitative), especially due to the need to validate these experimental models for practical application, can be classified into four central clusters: 1) Green hydrogen; 2) Economic Viability and Costs; 3) New Technologies; and 4) Public Policies and Case Studies, with different focuses that converging to the same objective, the use of hydrogen as an ecologically correct and profitable fuel to serve the energy production system from wind plants. From the results obtained, it is observed that the use of hydrogen as a fuel, and wind energy, are themes that have been relatively significant in recent years within the environment of industrial innovation, presenting an eclecticism, where several countries in a pulverized form are increasingly seeking invest in these technologies, which is expressed through the substantial growth in the number of papers published about these themes since 2000s.
\end{abstract}

Keywords: Fuel; Energy; Wind Energy; Hydrogen.

Resumo. Relação entre o hidrogênio e sua aplicação na energia eólica: uma revisão sistemática. 0 objetivo deste estudo foi mapear artigos sobre o uso do hidrogênio como combustível e a sua associação com a energia eólica situados em duas bases de dados (Web of Science e Scopus) a fim de apresentar caminhos para pesquisas na área e o contexto atual da produção científica desta. 0 estudo consistiu na revisão sistemática da literatura através da análise do conteúdo de 87 artigos provenientes dos bancos de dados da Web of Science e da Scopus.
Received

August 24, 2021

Accept

November 24, 2021

Available online November 24, 2021

Released

December 31, 2021

Open access

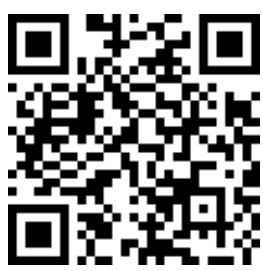

\section{ORCID}

D) 0000-0003-4640-6690 Matheus Eurico Soares de Noronha

(D) 0000-0001-6559-5111 André Themoteo da Silva Melo 
Os artigos foram analisados a partir de características descritivas, bibliográficas, metodológicas, de resultados e de citações. As publicações acerca deste tema têm sido majoritariamente desenvolvidas com modelos de pesquisa mistos (quantitativo e qualitativo), especialmente devido à necessidade de validar estes modelos experimentais para aplicação prática, podendo ser classificados em quatro temáticas centrais: 1) Green hydrogen; 2) Viabilidade econômica e custos; 3) Novas tecnologias; e 4) Políticas públicas e estudos de caso, com focos diferentes que acabam convergindo para um objetivo comum, o uso do hidrogênio como combustível ecologicamente correto e rentável para o atendimento do sistema de produção de energia a partir de usinas eólicas. 0 uso do hidrogênio como combustível, e a própria energia eólica, são temáticas relativamente pautadas de forma significativa há pouco tempo dentro do ambiente de inovação industrial, apresentando um ecleticismo significativo, onde diversos países de forma pulverizada estão procurando cada vez mais investir nestas tecnologias, o que é expresso por meio do substancial crescimento do número de artigos publicados acerca destas temáticas a partir dos anos 2000.

Palavras-chave: Combustível; Energia; Energia eólica; Hidrogênio.

\section{Introduction}

Regardless of the possibilities of energy sources for the future, currently there is already a broad need for methodologies for the production, storage, transportation and use of clean, safe, efficient, and versatile energy that can be delivered to the public on a massive basis (Sherif et al., 2005; Alavi et al., 2016). Once, it is a fact that electricity remains the most convenient form of energy used for centuries and can be produced from various sources and transported over large distances (Sherif et al., 2005; Lepszy et al., 2017).

In the context of recent environmental problems and disasters worldwide, with emphasis on global warming and the depletion of fossil fuels, wind power plants have been increasingly adopted throughout the world for electricity generation, especially because it is more competitive when compared to other renewable energy sources (Balat, 2005; Shishido et al., 2009; Alavi et al., 2016; Mostafaeipour et al., 2016; FernándezGuillamón et al., 2019). Wind energy production plants can have various configurations and operation patterns, and batteries are not necessarily the best solution for stabilizing the energy output, so other energy storage devices can be useful in this process. In other words, a proper system design is required according to the operation pattern of wind generators, and these operation patterns will become even more diverse in the future (Shishido et al., 2009; Lee et al., 2010). Clearly, in terms of the problems associated with the instability caused by wind turbines on the power grid, the importance of energy storage systems, particularly hydrogen fuel, has been increasingly significant (Balat, 2005; Alavi et al., 2016; Fernández-Guillamón et al., 2019).

Hydrogen stands out as a clean energy storage alternative, being efficient and versatile (Sherif et al., 2005). Shishido et al. (2009) report that an electrolysis-based hydrogen generator using wind power offers a much cleaner technology than hydrogen extraction by natural gas processing, which is accompanied by carbon dioxide emissions, 
or hydrogen generation by pyrolysis using nuclear energy. However, for hydrogen to play an important role in the energy sector in the future, at least in the medium and long term, it is necessary to have a capacity to produce hydrogen for energy purposes in an environmentally responsible and economical manner. To meet such circumstance, the power generated by the system should cover the load demand in the corresponding time and the surplus energy stored for later use (Al-Sharafi et al., 2017). And taking all this context into consideration, several studies have consensually verified that the transition to a hydrogen economy is not only a distant prospect for the future of renewable energy production, but also a reality that can be increasingly present, which has the potential to contribute to the total decarbonization of the world energy matrix (Sherif et al., 2005; Guandalini et al., 2015; Gondal et al., 2018).

The gap that this work seeks to fill is to present the main challenges and bottlenecks found in scientific productions related to hydrogen and wind energy. Additionally, it shows the main themes that are stressed by the literature and that require further research. This study was conducted with the objective of mapping papers on the use of hydrogen as a fuel and its association with wind energy located in two databases (Web of Science and Scopus) to present paths for research in the area and the current context of its scientific production.

\section{Methodology}

The methodological steps for the construction of the systematic review were guided by following the steps highlighted by Souza and Ribeiro (2013): (i) create a research problem that guides the research; (ii) choose the aspect to be analyzed in the literature; (iii) filter the collected data according to their relevance to the research problem; and (iv) analyze and interpret the data. The chosen databases were Scopus and Web of Science, considering the areas "Energy fuels", "Engineering Electrical Electronic", "Engineering environmental", "Green sustainable and technology" and "Renewable energy". It is noteworthy that the choice for these databases is due to the fact that they cover a universe containing the most relevant journals of these areas worldwide (Peçanha and Iizuka, 2014; Schmitt et al., 2013).

Only scientific papers published in journals that used a blind review process by peers were considered, without a pre-defined period in the research. The keywords searched were "Green hydrogen", "Hydrogen and wind energy", "Hydrogen and wind power", and "Hydrogen and wind source" considering the title, keywords and abstracts to collect the data and obtain the largest number of publications on the subject.

At first, 4,475 scientific papers published between 1974 and 2020 were found. Papers that were not related to the theme of the paper or were not scientific papers were excluded, reducing the number to 133 publications between 1991 and 2020. Then, papers that presented duplicity between the two platforms (the same paper appearing in both) were excluded, reducing the number of scientific papers to 87 , and these were published between 1991 and 2020 (Figure 1).

The papers were classified according to descriptive characteristics (journals, country, and year of publication) and methodological (research method), in addition to the results (main theme of the research) and citations. All selected papers were managed by database plotted in Microsoft Excel with the reference of each publication and its basic information (abstract, keywords, database, type of work among others). The Atlas T.I. software was also used for the separation and categorization of the thematic divisions identified in the results analysis. The software also collaborated with the refinement and segregation of the material present in the databases.

Rev. Bras. Gest. Amb. Sustent., 2021, vol. 8, n. 20, p. 1295-1313. 


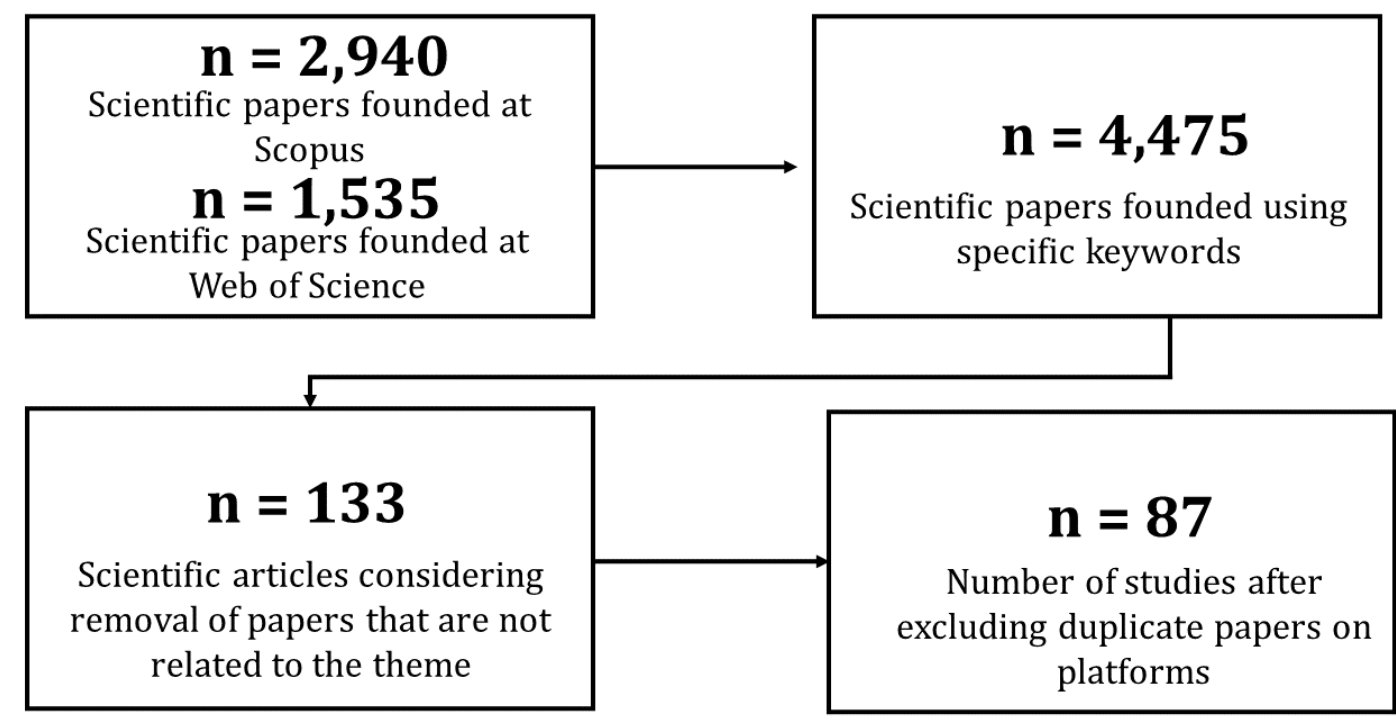

Figure 1. Flow diagram of the systematic review.

\section{Analysis and discussion of the results}

Considering the scope of the research, the results of the analysis of the data collected indicated that the "International Journal of Hydrogen Energy" concentrates most of the papers mapped on hydrogen as a fuel and its relationship with wind energy. Even though other periodicals also stood out to some extent, these are still quite distant and present a production that is little objectively directed towards this theme (Table 1). There was also a broad concentration of journals in the most comprehensive publishers, with Elsevier standing out, concentrating more than half of the bibliographical material mapped on hydrogen and wind energy. Furthermore, it was found that all the journals that were mapped out were required to be written in English, regardless of the journal's country of origin.

Table 1. Journals that were most cited in the survey $(+3)$.

\begin{tabular}{|l|c|c|c|}
\hline Periodical & Publisher & Country oforigin & Frequency \\
\hline International Journal of Hydrogen Energy & Elsevier & Netherlands & 35 \\
\hline Applied Energy & Elsevier & Netherlands & 5 \\
\hline Energy Procedures & Elsevier & Netherlands & 3 \\
\hline JournalofCleanerProduction & Elsevier & Netherlands & 3 \\
\hline Journal of Power Sources & Elsevier & Netherlands & 3 \\
\hline Renewable and Sustainable Energy Reviews & Elsevier & Netherlands & 3 \\
\hline Renewable Energy & Hindawi & United Kingdom & 3 \\
\hline
\end{tabular}

An analysis of the countries that presented the most papers among the studies mapped on hydrogen and wind energy (Table 2) shows that three countries stood out in the publication of papers on these subjects (Canada, China, and Spain). Probably the two main common points in these countries, and consequently this is reflected in the studies, are the fact that these three countries have a coastal zone for the potential use of hydrogen production, which creates a favorable environment for the use of offshore wind to supply 
wind power plants; in addition to prioritizing investments in the construction of a business environment that encourages science, technology and innovation, which are fundamental when thinking of wind energy as a source of electricity that can be predominant for the electricity system in the medium and long term (Olateju and Kumar, 2011; Garmsiri et al., 2014; Olateju et al., 2014; Ramos and Iglesias, 2014; Zhang and Wan, 2014; Martin and Grossmann, 2017; Li et al., 2018; Fernández-Guillamón et al., 2019; Sun et al., 2019; Huang and Liu, 2020).

In the past, some countries that also have a large coastal area but do not have this environment that encourages science, technology, and innovation to use the wind source for the production of hydrogen were verified, with Brazil being the most classic example of this observation (Silva et al., 2005; Nadaleti et al., 2020a; Nadaleti et al., 2020b). In this sense, Silva et al. (2005) already commented at the beginning of the century that countries like Brazil have an enormous potential for energy production from renewable sources, which can exceed the internal energy demand and give rise to a surplus of energy production. This surplus of electric energy may even represent a new energy market characterized by the possibility of exporting this surplus through hydrogen to other countries that do not have such a significant renewable energy potential and are willing to increase the participation of renewable sources in their energy system mix to reduce the use of non-renewable energy.

Table 2. Distribution of papers according to the country of origin of the study.

\begin{tabular}{|c|c|c|}
\hline Country & Number of papers & Percentage (\%) \\
\hline Canada & 7 & 8.05 \\
\hline China & 7 & 8.05 \\
\hline Spain & 7 & 8.05 \\
\hline United States ofAmerica & 6 & 6.90 \\
\hline Iran & 6 & 6.90 \\
\hline Germany & 5 & 5.75 \\
\hline Japan & 4 & 4.60 \\
\hline Turkey & 4 & 4.60 \\
\hline Algeria & 3 & 3.45 \\
\hline Brazil & 3 & 3.45 \\
\hline Italy & 3 & 3.45 \\
\hline $\begin{array}{l}\text { Belgium, Chile, Denmark, Greece, } \\
\text { Netherlands, Ireland, Pakistan, South } \\
\text { Africa and United Kingdom }\end{array}$ & 2 & 2.30, each \\
\hline $\begin{array}{l}\text { Saudi Arabia, Argentina, Austria, } \\
\text { Colombia, Fiji, Finland, France, India, } \\
\text { Norway, Poland, South Korea, Scotland, } \\
\text { Ukraine, and Vietnam }\end{array}$ & 1 & 1.15 , each \\
\hline
\end{tabular}

This eclecticism about the countries that have published studies on hydrogen as fuel and its relationship with wind energy, consequently indicating an investment in this type of technology, is also related to the papers that presented the highest number of citations (Table 3). Among the ten most cited papers, there was no repetition of countries among the studies, i.e., each study was developed in a different country, indicating that the development of these technologies is not concentrated in a few centers. Sherif et al. (2005) was the most cited among those mapped, justifying this result by the fact that this article is a very complete review of the technological aspects of wind energy and the use of 
hydrogen as a fuel. This study presents a specific focus on the economic part, indicating that all the benefits of hydrogen as an environmentally beneficial fuel will only be widely enjoyed when hydrogen is produced from renewable energy sources where wind energy has an outstanding role. In addition, hydrogen can be used as an energy storage medium in some applications, thus increasing the competitiveness of wind energy. However, the economics of such integrated systems depend on the availability of wind, cost of the individual components (most prominently electrolyzers, hydrogen storage and fuel cells), usage dynamics and utilization factors and finally the cost of competitive technologies.

Table 3. Most cited papers up to the moment of the study (+50).

\begin{tabular}{|c|c|c|c|}
\hline № & Papers & Citations & Main result of the study \\
\hline 1 & Sherif et al. (2005) & 251 & $\begin{array}{l}\text { The use of hydrogen as a fuel increases the } \\
\text { competitiveness of the wind energy model. }\end{array}$ \\
\hline 2 & Gonzalez-Aparicio et al. (2018) & 222 & $\begin{array}{l}\text { The wind producer can increase profits by } \\
\text { integrating methanol production into the wind } \\
\text { plant, rather than just producing and selling all } \\
\text { the energy produced to the energy market. }\end{array}$ \\
\hline 3 & Shishido et al. (2009) & 168 & $\begin{array}{l}\text { Proposition of a new model for wind power } \\
\text { generator, where it showed good efficacy } \\
\text { inexperimental level. }\end{array}$ \\
\hline 4 & Guandalini et al. (2015) & 147 & $\begin{array}{l}\text { Evaluated the potential of power-to-gas } \\
\text { technology for energy balancing to estimate its } \\
\text { effectiveness in balancing the power produced } \\
\text { by a large group of wind plants. }\end{array}$ \\
\hline 5 & Lepszy et al. (2017) & 97 & $\begin{array}{l}\text { The ratio between the energy generated from } \\
\text { the wind power plant and the storage system } \\
\text { is significant. Due to the low efficiency in this } \\
\text { process, the development of each element of } \\
\text { the system needs to be revisited. }\end{array}$ \\
\hline 6 & Al-Sharafi et al. (2017) & 92 & $\begin{array}{l}\text { The production of hydrogen through } \\
\text { renewable energy (solar and wind) makes it } \\
\text { possible to have an environmentally friendly } \\
\text { fuel. }\end{array}$ \\
\hline 7 & Gonzalez et al. (2004) & 71 & $\begin{array}{l}\text { Even allowing for significant cost reductions, } \\
\text { the low average cost of surplus electricity and } \\
\text { a high market price for hydrogen are also } \\
\text { necessary to achieve economic viability for the } \\
\text { technology. }\end{array}$ \\
\hline 8 & Sarrias-Mena et al. (2015) & 63 & $\begin{array}{l}\text { To enhance the growth of renewable energy, } \\
\text { the implementation of hybrid systems is } \\
\text { considered a viable alternative that aggregates } \\
\text { the benefits of the various energy sources } \\
\text { involved. }\end{array}$ \\
\hline 9 & Mostafaeipour et al. (2016) & 54 & $\begin{array}{l}\text { Hydrogen production from renewable energy } \\
\text { sources, such as wind power, is becoming a } \\
\text { hot topic in many countries, mainly due to the } \\
\text { positive environmental impact. }\end{array}$ \\
\hline 10 & Lee et al. (2010) & 50 & $\begin{array}{l}\text { Examined the competitiveness of a hydrogen } \\
\text { production station from wind energy in } \\
\text { environmental and economic aspects by } \\
\text { analyzing the future conditions in two } \\
\text { scenarios. }\end{array}$ \\
\hline
\end{tabular}


Gonzalez-Aparicio (2018), meanwhile, the second most cited, explores in a bold and innovative scope the necessary conditions for an environmentally and economically viable carbon dioxide utilization system for methanol production using a typical wind power generation system to maximize total profit. The core of this business model proposed by the authors is based on the following contexts: (i) sale of wind energy in the day-ahead or intraday bids of the energy market or, (ii) production of methanol for sale to third parties. The study in question presented in its results that producing methanol instead of just selling the energy generated by the wind plant is more profitable, where the wind plant can be up to three times smaller than the conventional one. In addition, the wind producer could increase profits by up to $33 \%$ by integrating the production of methanol into its business strategy, instead of selling all the energy produced on the energy market.

In an effort to categorize or even identify patterns concerning the scope of the mapped papers it was found that the research model of studies on the use of hydrogen as a fuel associated with wind energy (Figure 2) presents a preference for mixed research models (quantitative and qualitative) (45.98\%), where results were evaluated both in a parametric analysis approach (use of statistical tests, linear or polynomial regression etc.) and non-parametric (results analyzed by non-parametric tests or using a descriptive analysis. ) as well as non-parametric (results analyzed by non-parametric tests or using a descriptive analysis, which was mostly verified in the mapped studies). The other studies on these themes presented a solely quantitative approach $(32.18 \%)$, where results were analyzed parametrically; or theoretical $(21.84 \%)$, where literature reviews and studies dedicated to discussing theory, concepts and ideas on the subject in question are included.

These results are widely associated with the fact that the theme of hydrogen as a fuel associated with wind energy is rapidly rising in the experimental scenario, which implies the need to conduct studies with methodologies that allow the evaluation of the results both in quantitative and qualitative aspects to validate these experimental models for practical application. Based on this premise, it is expected that the quantitative methodology is the second most applied in the mapped studies, especially to evaluate the results parametrically. Furthermore, it is interesting to note that none of the mapped studies in question presented a solely qualitative approach, preferring to polarize between the use of a mixed or quantitative approach, and a merely theoretical approach to evaluate what is already present in the literature about this theme. Another important point to be highlighted is the fact that there is, especially among the studies with mixed methodology, a constant predilection for the use of case studies to evaluate innovative models that test the effectiveness of the use of hydrogen as a fuel associated with wind energy.

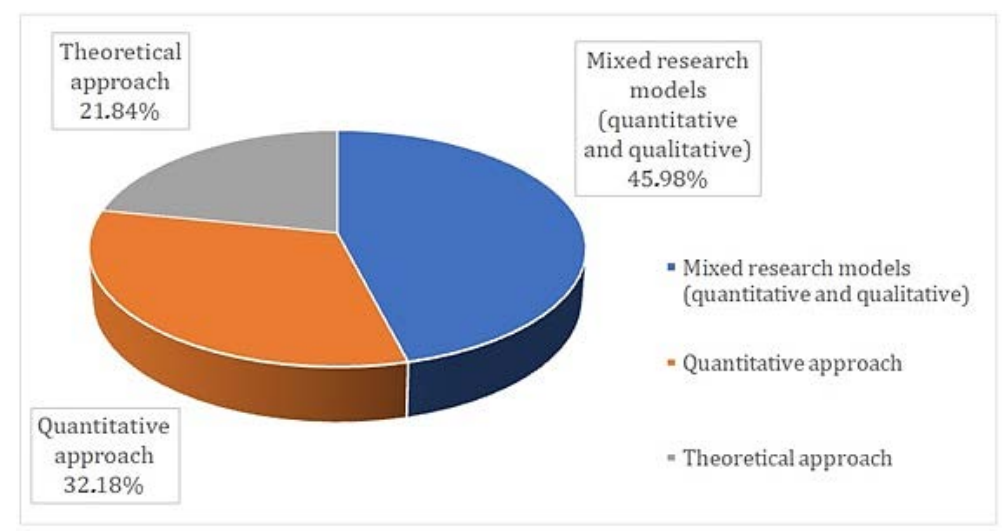

Figure 2. Papers categorized according to the methodology applied. 
When it comes to the conceptual part, it was verified that the theme "hydrogen as fuel from wind energy" could not be worked on in separate topics because they were somehow interconnected in all the mapped works. Based on this principle, four large topics (clusters) between hydrogen as fuel and wind energy were identified: 1) Green Hydrogen; 2) Economic Viability and Costs; 3) New Technologies; and 4) Public Policies and Case Studies (Table 4). All these areas, despite being in the same research context and converging to the same theme (Figure 3), present different nuances and study focuses, however, with the common objective of validating the use of hydrogen as an ecologically correct and economically viable fuel in broad association with wind energy production plants.

Table 4. Papers categorized according to the scope of the study.

\begin{tabular}{|c|c|}
\hline Studyarea & Papers \\
\hline 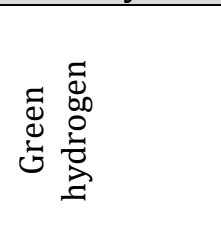 & $\begin{array}{l}\text { Kameyama et al. (2011); Sheth et al. (2011); Troncoso and } \\
\text { Newborough (2011); Dagdougui et al. (2012); Zhao et al. (2018); } \\
\text { Armijo and Philibert (2019); Ayodele and Munda (2019a); Ayodele } \\
\text { Munda (2019b); Gondal (2019); Olmos et al. (2019); Amica et al. } \\
\text { (2020); Huang and Liu (2020); Kudriaet al. (2020); Nadaleti et } \\
\text { al.(2020a) }\end{array}$ \\
\hline 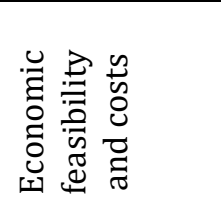 & $\begin{array}{l}\text { Sherif et al. (2005); Lee et al. (2010); Yumurtac and Toprak (2011); } \\
\text { Guandalini et al. (2015); Al-Sharafi et al. (2017); Nagasawa et al. } \\
\text { (2019); Rezaei et al. (2019); Jahangiri et al. (2019); Berg et al. } \\
\text { (2020); Nicita et al. (2020) }\end{array}$ \\
\hline 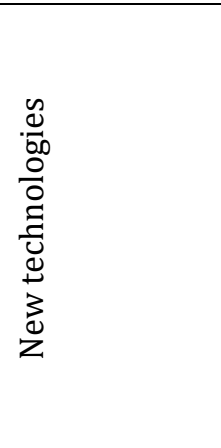 & $\begin{array}{l}\text { Dienhart and Siegel (1994); Yang and Aydin (2001); Shishido et al. } \\
\text { (2009); Muyeen et al. (2010); Koroneos and Katopodi (2011); Veja et } \\
\text { al. (2011) Weidong and Zhuoyong (2012); Carr et al. (2013); } \\
\text { Garmsiri et al. (2014); Olateju et al. (2014); Zhang and Wan (2014); } \\
\text { Khaitan et al. (2015); Sarrias-Mena et al. (2015); Realpe-Jiménez et } \\
\text { al. (2015); Martín (2016); Martin and Grossmann (2017); Franzen } \\
\text { and Madlener (2017); Mueller et al. (2017); Kılkış (2017); Bhogilla et } \\
\text { al. (2017); Lepszy et al. (2017); Ishaq et al. (2018); Li et al. (2018); } \\
\text { Safari and Dincer (2018); Ishaq and Dincer (2019); Fasihi and Breyer } \\
\text { (2019); Fernández-Guillamón et al. (2019); Sun et al. (2019); Ishaq } \\
\text { and Dincer (2020). }\end{array}$ \\
\hline 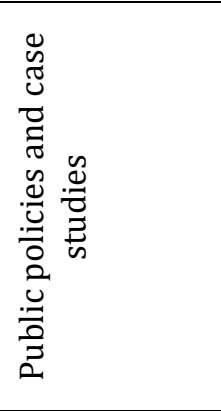 & $\begin{array}{l}\text { Braun et al. (1991); Gonzalez et al. (2004); Mönnich et al. (2004); } \\
\text { Balat (2005); Silva et al. (2005); Gazey et al. (2006); Schenk et al. } \\
\text { (2007); Yang (2008); Aiche-Hamane et al. (2009); Zolezzi et al. } \\
\text { (2010); Dagdougui et al. (2011); Olateju and Kumar (2011); Genç et } \\
\text { al. (2012); Shi et al. (2013); Kaldellis et al. (2013); Ramose Iglesias } \\
\text { (2014); Al Zohbi et al. (2015); Douak and Settou (2015); Frueh } \\
\text { (2015); Burkhardt et al. (2016); Mostafaeipour et al. (2016); Alavi et } \\
\text { al. (2016); Ashrafi et al. (2018); Rezaei et al. (2018); Gondal et al. } \\
\text { (2018); Blal et al. (2018); Gonzalez-Aparicio et al. (2018); Kodicherla } \\
\text { et al. (2018); Mostafaeipour et al. (2020); Ostadi et al. (2020) }\end{array}$ \\
\hline
\end{tabular}




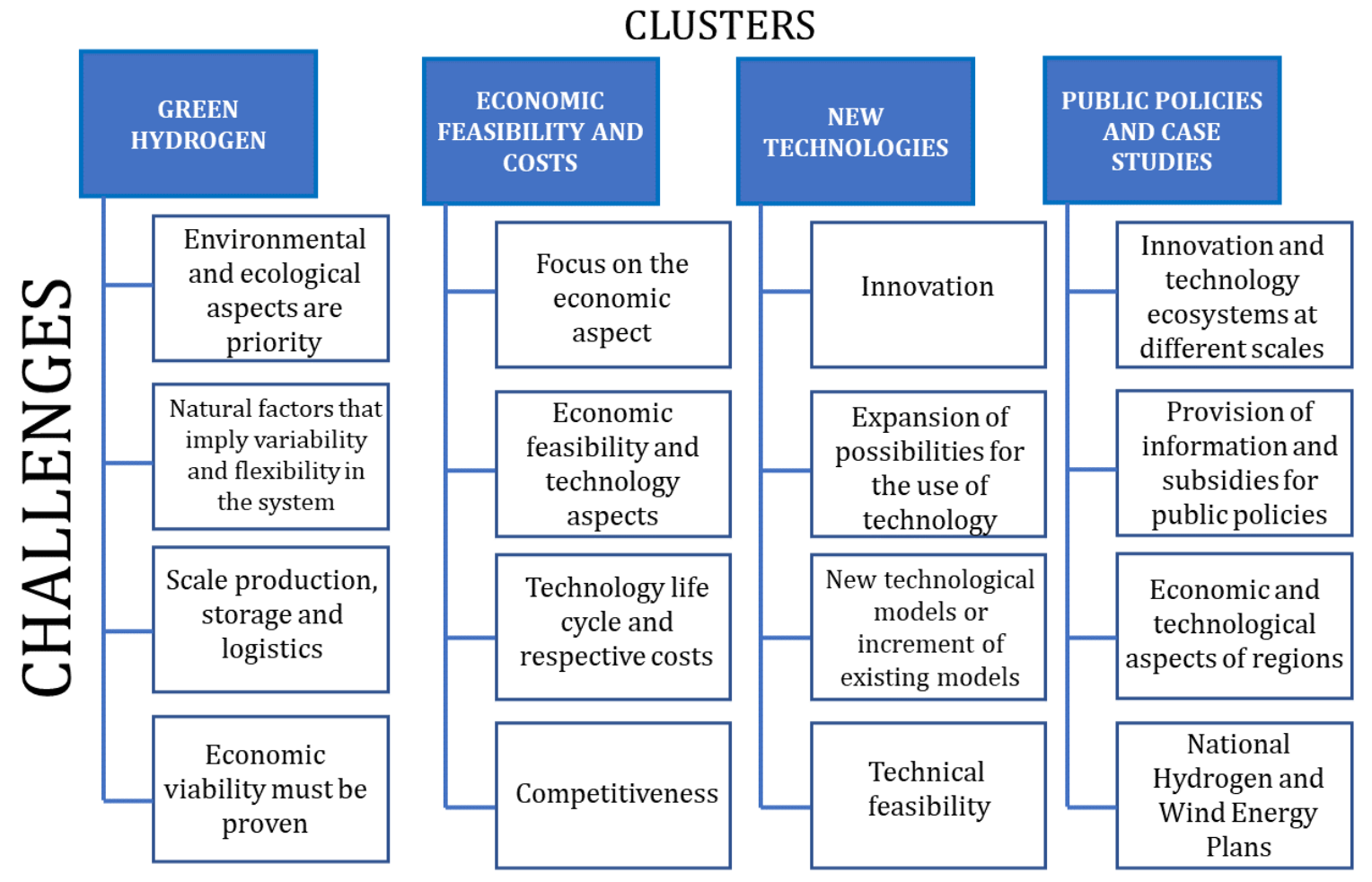

Figure 3. Association between the conceptual areas and their challenges.

Initially, when addressing the issue of "Green Hydrogen", it should be remembered that the fact that much of the hydrogen production at the industrial level is currently still dependent on the use of fossil fuels (Nadaleti et al., 2020a; 2020b; Proost, 2020). However, according to Nadaleti et al. (2020a,b), new perspectives point to an energy production increasingly less dependent on these fuels, especially using renewable and environmentally friendly sources, and this is where the concept of "green hydrogen" fits in, where hydrogen production is completely free from the use of fossil fuels, does not produce waste that harms the environment (Ostadi et al., 2020), and can provide clean energy for some of the main sectors of the economy, such as industry, infrastructure and transportation (Rabiee et al., 2021). Rabiee et al. (2021), envisioning a carbon-free energy chain via "green hydrogen" in the medium to long term, comments that this can be achieved by the following means:

- By producing "green hydrogen", the need for "blue hydrogen" (i.e. hydrogen extracted from natural gas through the steam methane reforming process) and therefore the generation of $\mathrm{CO}_{2}$ will be reduced;

- The green hydrogen generated may be injected into the natural gas grid up to a specific percentage. For this capacity, the amount of natural gas consumption will be decreased compared to the case of no green hydrogen; and

- Green hydrogen can be stored and used in marine, aviation, and other transportation systems through the hydrogen supply chain.

A key issue within this theme concerns the temporal variation of wind and sun, the main factors influencing the share of renewable energy in the global energy system, especially from the perspective of how this variability affects the production costs of $\mathrm{H}_{2}$, 
$\mathrm{NH}_{3}$ or synthetic carbon-based fuels (Troncoso and Newborough, 2011; Dagdougui et al., 2012; Armijo and Philibert, 2019). However, most of the studies already conducted about hydrogen production from environmentally friendly fuels have avoided addressing this issue of variation as they consider this a factor inherent to the very nature of the wind source. In this sense, a full understanding of the role of flexibility is therefore still in the process of construction, especially when also considering the open question of the possible interest in combining wind and solar energy to reduce this variability and thus reduce the production costs of so-called green fuels (Rezaei et al., 2018; Armijo and Philibert, 2019).

Furthermore, when one considers this theme from a market perspective, one verifies that regardless of future energy sources, there will always be the need for clean, safe, efficient, and versatile forms of energy that can be delivered to the end user. Given this premise, the analysis of their economic feasibility to enable the technology to be applied in scale becomes increasingly essential (Sherif et al., 2005; Lee et al., 2010; Guandalini et al., 2015; Nicita et al., 2020).

This reasoning leads us to the cluster "Economic Feasibility and Costs", where several authors have found that wind energy can be produced at a very low cost in regions with sufficient wind resources and can be used to generate hydrogen at low or large scale (Sherif et al., 2005; Lee et al., 2010; Guandalini et al., 2015; Jahangiri et al., 2019; Rezaei et al., 2019). And to meet the consumption demand, hydrogen can be transported and distributed regionally, in gaseous or liquid form, by pipelines or, in special cases, in containers, by road and rail transport. However, this transportation of gaseous and liquid hydrogen is subject to strict regulations to ensure public safety, which in some countries is very restrictive (Yumurtac and Toprak, 2011; Rezaei et al., 2019). Another point to be highlighted, which relates to the following theme, is connected to the economic viability of innovative technologies and the impact they have on the profitability of the productive enterprise. In this sense, a case to be highlighted is related to theProton Exchange Membrane (PEM) technology, which is a proton membrane that enables the production of hydrogen from the surplus generation in a wind power plant. This generated hydrogen can later be used for electricity generation in fuel cells, different vehicle transport or chemical industry. However, this technology, like others, represents a technological and economic challenge because it still presents substantial result variations related to the model that must be applied to achieve an efficient performance that brings an economically viable return for the industry (Lee et al., 2010; Sarrias-Mena et al., 2015).

When the cluster"New Technologies" is addressed, studies focus on the testing, evaluation and, possibly, validation of new technological possibilities to produce hydrogen from wind power plants (Khaitan et al., 2015; Martin, 2016; Sun et al., 2019). In this approach, the watchword is innovation, where there is a need for the search of new energy sources that are aligned with the environmental agenda, creating a growing demand for the technology sectors to develop new systems or increase existing technologies. Moreover, this theme is connected to the previous theme, since it is from the advent of technical validation of these new technologies that one seeks strategies to optimize production while being able to reduce costs and make the enterprise also economically viable (Dienhart and Siegel, 1994; Sarrias-Mena et al., 2015; Li et al., 2018; Fasihi and Breyer, 2019).

Studies under the cluster "Public Policies and Case Studies" focus on research that considers hydrogen fuel technology and its relationship with wind energy in each specific technological and business ecosystem (Gonzalez et al., 2004; Mönnich et al., 2004; Mostafaeipour et al., 2016; Rezaei et al., 2018). In the case, one ends up addressing the experience of cities, states, provinces, or countries in applying that technology or developing new technologies from that premise. With the results of these surveys and data analysis, it becomes possible to formulate incentive and development policies for 
technologies applied to the production of hydrogen from wind energy. Some countries have stood out in this regard, especially because they are well advanced in the consolidation of these public policies, such as Germany, Chile and the Netherlands (González et al., 2004; Zolezzi et al., 2010; González-Aparicio et al., 2018). Countries such as Algeria, Argentina, India, Pakistan, Turkey, Ukraine, and South Africa are still in the feasibility testing phase of building a public policy (Balat, 2005; Al Zohbi et al., 2015; Douak and Settou, 2015). It is also worth mentioning that these policies cover P\&D for the development of new related technologies, credit lines for technology application, tax incentives, market relations among other instruments associated with the governance of each of these business ecosystems (Balat, 2005; Al Zohbi et al., 2015; Douak and Settou, 2015; Alavi et al., 2016; Gondal et al., 2018).

In another approach, considering the model of wind energy production system used in the mapped studies (Figure 4), it was found that most of these studies showed predilection for the use of hybrid models (51.72\%), where hydrogen is produced by more than one renewable energy source, usually being wind and solar (Dagdougui et al., 2012; Martin, 2016; Al-Sharafi et al., 2017; Martin, 2017; Blal et al., 2018). Furthermore, there is a subsequent predilection for the use of onshore systems (39.08), where infrastructure generates energy from wind blowing at onshore locations (Sheth et al., 2011; Bhogilla et al., 2017; Lepszy et al., 2017; Sun et al., 2019), with little research directed towards offshore systems $(9.20 \%)$, where clean and renewable energy is obtained by harnessing the strength of the wind blowing offshore, where it reaches a higher and more constant speed due to the absence of barriers (Shi et al., 2013; Fernández-Guillamón et al., 2019; Gondal, 2019).

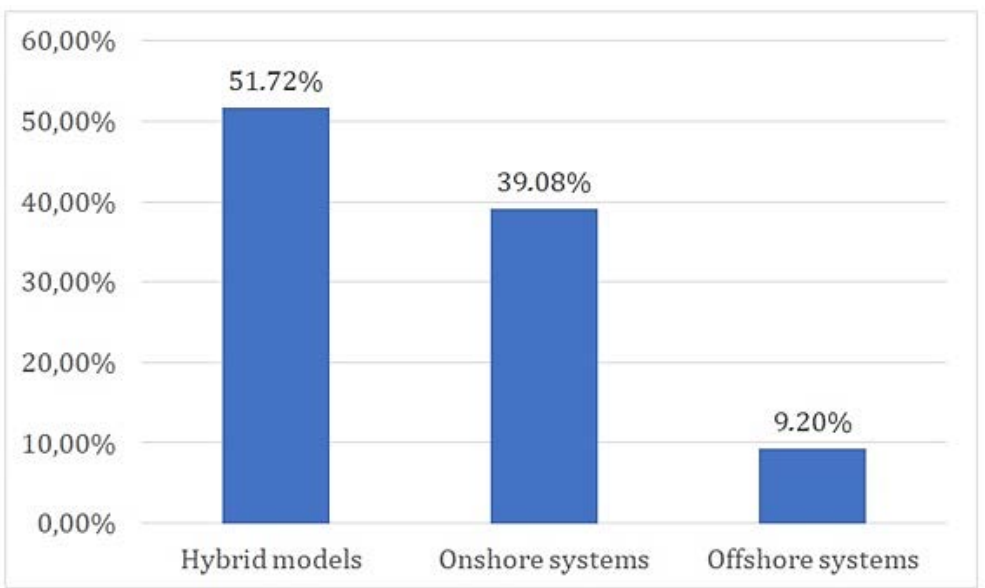

Figure 4. percentages of items mapped according to the wind plant model adopted.

When analyzing the sample space of time of the mapped papers (Figure 5), publications started at a relatively low level in the 1990s, with a significant increase in the 2000s, especially as of 2009. This particular interest in the use of hydrogen as a fuel and its broad association with wind energy is in line with the new perspectives and environmental agendas that have increasing force at the global level. The working groups on science and technology no longer see room for proposals that do not seek an environment of innovation for environmentally friendly energy production (Shishido et al., 2009; Lee et al., 2010; Mostafaeipour et al., 2016). And from this perspective, it is 
observed a natural interest in research and development of technologies on this theme, which consequently implies in a greater number of published papers.

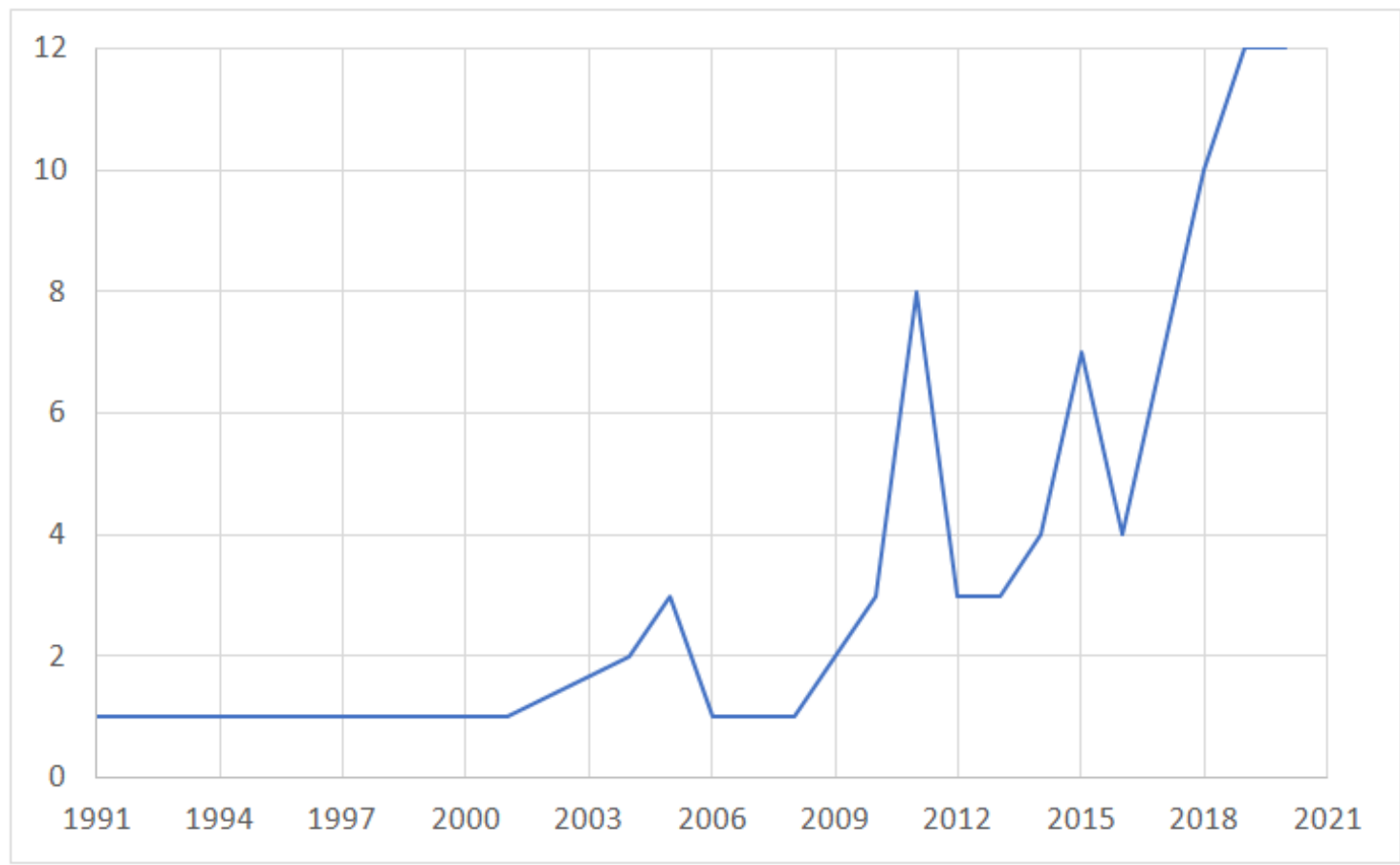

Figure 5. Number of papers published per year considering the period from 1991 to 2020.

\section{Conclusions}

Based on the results obtained, the use of hydrogen as a fuel and wind energy itself are themes that have recently been significantly regulated within the industrial innovation environment, presenting a significant eclecticism. Different countries are increasingly seeking to invest in these technologies, which is expressed through the substantial growth in the number of papers published on these themes as of the 2000s.

Studies on this theme have been mostly developed with mixed research models (quantitative and qualitative), especially due to the need to validate these experimental models for practical application, and can be classified into four central clusters: 1) Green hydrogen; 2) economic feasibility and costs; 3) new technologies; and 4) public policies and case studies, with different focuses that end up converging towards a common objective, the use of hydrogen as an ecologically correct and profitable fuel to serve the energy production system from wind power plants. Furthermore, as to the perspective of the model adopted for the practical production of wind power, it was verified that although countries that present a significant coastal zone (offshore) institutionally indicate a more prominent focus on technologies related to wind power, these are much less adopted than onshore and hybrid models.

Taking this theme into consideration, it is possible to outline some challenges related to the future of the development of technologies related to the production of hydrogen from renewable sources, especially wind energy, highlighting the following points: a) priorities in relation to environmental and ecological aspects; b) scale of 
production and logistics; c) economic viability of production and the costs involved in the technology; d) market competitiveness in relation to other energy sources; e) new technologies and innovation ecosystem; and f) provision of information and subsidies for public policies among other crucial points for its development in the technical and scientific sphere.

\section{Conflicts of interest}

The authors declare that have no conflicts of interest.

\section{References}

Aiche-Hamane, L.; Belhamel, M.; Benyoucef, B.; Hamane, M. Feasibility study of hydrogen production from wind power in the Region of Ghardaia. International Journal of Hydrogen Energy, v. 34, no. 11, p. 4947-4952, 2009. https://doi.org/10.1016/j.ijhydene. 2008.12.037

Al Zohbi, G.; Hendrick, P.; Bouillard, P. Wind characteristics and wind energy potential analysis in five sites in Lebanon. International Journal of Hydrogen Energy, v. 40, no. 44, p. 15311-15319, 2015. https://doi.org/10.1016/j.ijhydene.2015.04.115

Alavi, O.; Mostafaeipour, A.; Qolipour, M. Analysis of hydrogen production from wind energy in the southeast of Iran. International Journal of Hydrogen Energy, v. 41, no. 34, p. 15158-15171, 2016. https://doi.org/10.1016/j.ijhydene.2016.06.092

Al-Sharafi, A.; Sahin, A. Z.; Ayar, T.; Yilbas, B. S. Techno-economic analysis and optimization of solar and wind energy systems for power generation and hydrogen production in Saudi Arabia. Renewable and Sustainable Energy Reviews, v. 69, p.33-49, 2017. https://doi.org/10.1016/j.rser.2016.11.157

Amica, G.; Arneodo Larochette, P.; Gennari, F. C. Light metal hydride-based hydrogen storage system: Economic assessment in Argentina. International Journal of Hydrogen Energy, v. 45, no. 38, p.18789-18801, 2020. https://doi.org/10.1016/j.ijhydene.2020. 05.036

Armijo, J.; Philibert, C. Flexible production of green hydrogen and ammonia from variable solar and wind energy: Case study of Chile and Argentina. International Journal of Hydrogen Energy, v. 45, no. 3, p. 1541-1558, 2019. https://doi.org/10.1016/j.ijhydene. 2019.11.028

Ashrafi, Z. N.; Ghasemian, M.; Shahrestani, M. I.; Khodabandeh, E.; Sedaghat, A. Evaluation of hydrogen production from harvesting wind energy at high altitudes in Iran by three extrapolating Weibull methods. International Journal of Hydrogen Energy, v. 43, no. 6, p. 3110-3132, 2018. https://doi.org/10.1016/j.ijhydene.2017.12.154

Ayodele, T. R.; Munda, J. L. Potential and economic viability of green hydrogen production by water electrolysis using wind energy resources in South Africa. International Journal of Hydrogen Energy, v. 44, no. 33, p. 17669-17687, 2019a. https://doi.org/10.1016/ j.ijhydene.2019.05.077

Ayodele, T. R.; Munda, J. L. The potential role of green hydrogen production in the South Africa energy mix. Journal of Renewable and Sustainable Energy, v. 11, no. 4, 044301, 2019b. https://doi.org/10.1063/1.5089958

Balat, H. Wind energy potential in Turkey. Energy Exploration \& Exploitation, v. 23, no. 1, p. 51-59, 2005. https://doi.org/10.1260/0144-5987.23.1.51 
Berg, T. L.; Apostolou, D.; Enevoldsen, P. Analysis of the wind energy market in Denmark and future interactions with an emerging hydrogen market. International Journal of Hydrogen Energy, v. 46, no. 1, p.146-156, 2020. https://doi.org/10.1016/j.ijhydene. 2020.09.166

Bhogilla, S. S.; Ito, H.; Segawa, T.; Kato, A.; Nakano, A. Experimental study on laboratory scale Totalized Hydrogen Energy Utilization System using wind power data. International

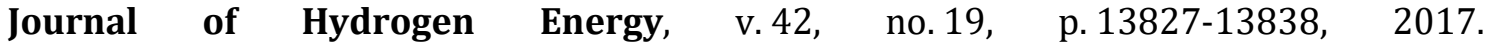
https://doi.org/10.1016/j.ijhydene.2016.12.125

Blal, M.; Belasri, A.; Benatillah, A.; Hamouda, M.; Lachtar, S.; Sahouane, N.; Labiri, S.; Mostefaoui, M. Assessment of solar and wind energy as motive for potential hydrogen production of Algeria country; development a methodology for uses hydrogen-based fuel cells. International Journal of Hydrogen Energy, v. 43, no. 19, p. 9192-9210, 2018. https://doi.org/10.1016/j.ijhydene.2018.03.200

Braun, G. W.; Suchard, A.; Martin, J. Hydrogen and electricity as carriers of solar and wind energy for the 1990s and beyond. Solar Energy Materials, v. 24, no. 1/4, p. 62-75, 1991. https://doi.org/10.1016/0165-1633(91)90048-P

Burkhardt, J.; Patyk, A.; Tanguy, P.; Retzke, C. Hydrogen mobility from wind energy: A life cycle assessment focusing on the fuel supply. Applied Energy, v. 181, p. 54-64, 2016. https://doi.org/10.1016/j.apenergy.2016.07.104

Carr, S. J. W.; Thanapalan, K. K. T.; Zhang, F.; Guwy, A. J.; Maddy, J.; Gusig, L.-O.; Premier, G. C. Integration of wind power and hydrogen hybrid electric vehicles into electric grids. Smart Innovation, Systems and Technologies, v. 2, p. 261-270, 2013. https://doi.org/10.1007/978-3-642-36645-1_24

Dagdougui, H.; Ouammi, A.; Sacile, R. A regional decision support system for onsite renewable hydrogen production from solar and wind energy sources. International Journal of Hydrogen Energy, v. 36, no. 22, p. 14324-14334, 2011. https://doi.org/ 10.1016/j.ijhydene.2011.08.050

Dagdougui, H.; Ouammi, A.; Sacile, R. Modelling and control of hydrogen and energy flows in a network of green hydrogen refuelling stations powered by mixed renewable energy systems. International Journal of Hydrogen Energy, v. 37, no. 6, p. 5360-5371, 2012. https://doi.org/10.1016/j.ijhydene.2011.07.096

Dienhart, H.; Siegel, A. Hydrogen storage in isolated electrical energy systems with photovoltaic and wind energy. International Journal of Hydrogen Energy, v. 19, no. 1, p. 61-66, 1994. https://doi.org/10.1016/0360-3199(94)90178-3

Douak, M.; Settou, N. Estimation of hydrogen production using wind energy in Algeria. Energy Procedia, v. 74, p. 981-990, 2015. https://doi.org/10.1016/j.egypro.2015.07.829

Fasihi, M.; Breyer, C. Base load electricity and hydrogen supply based on hybrid PV-wind power plants. Journal of Cleaner Production, v. 243, 118466, 2019. https://doi.org/ 10.1016/j.jclepro.2019.118466

Fernández-Guillamón, A.; Das, K.; Cutululis, N. A.; Molina-García, Á. Offshore wind power integration into future power systems: Overview and trends. Journal of Marine Science and Engineering, v. 7, no. 11, 399, 2019. https://doi.org/10.3390/jmse7110399

Franzen, S.; Madlener, R. Optimal expansion of a hydrogen storage system for wind power (H2-WESS): A real options analysis. Energy Procedia, v. 105, p. 3816-3823, 2017. https://doi.org/10.1016/j.egypro.2017.03.891 
Früh, W.-G. From local wind energy resource to national wind power production. AIMS Energy, v. 3, no. 1, p. 101-120, 2015. https://doi.org/10.3934/energy.2015.1.101

Garmsiri, S.; Rosen, M.; Smith, G. Integration of wind energy, hydrogen and natural gas pipeline systems to meet community and transportation energy needs: A parametric study. Sustainability, v. 6, no. 5, p. 2506-2526, 2014. https://doi.org/10.3390/ su6052506

Gazey, R.; Salman, S. K.; Aklil-D’Halluin, D. D. A field application experience of integrating hydrogen technology with wind power in a remote island location. Journal of Power Sources, v. 157, no. 2, p. 841-847, 2006. https://doi.org/10.1016/j.jpowsour.2005.11.084

Genç, M.S.; Çelik, M.; Karasu, İ. A review on wind energy and wind-hydrogen production in Turkey: A case study of hydrogen production via electrolysis system supplied by wind energy conversion system in Central Anatolian Turkey. Renewable and Sustainable Energy Reviews, v. 16, no. 9, p.6631-6646, 2012. https://doi.org/10.1016/ j.rser.2012.08.011

Gondal, I. A.; Masood, S. A.; Khan, R. Green hydrogen production potential for developing a hydrogen economy in Pakistan. International Journal of Hydrogen Energy, v. 43, no. 12, p. 6011-6039, 2018. https://doi.org/10.1016/j.ijhydene.2018.01.113

Gondal, I. Offshore renewable energy resources and their potential in a green hydrogen supply chain through power-to-gas. Sustainable Energy \& Fuels, v. 3, p. 1468-1489, 2019. https://doi.org/10.1039/C8SE00544C

González, A.; McKeogh, E.; Gallachóir, B. Ó. The role of hydrogen in high wind energy penetration electricity systems: The Irish case. Renewable Energy, v. 29, no. 4, p. 471-489, 2004. https://doi.org/10.1016/j.renene.2003.07.006

González-Aparicio, I.; Kapetaki, Z.; Tzimas, E. Wind energy and carbon dioxide utilisation as an alternative business model for energy producers: A case study in Spain. Applied Energy, v. 222, p. 216-227, 2018. https://doi.org/10.1016/j.apenergy.2018.03.114

Guandalini, G.; Campanari, S.; Romano, M. C. Power-to-gas plants and gas turbines for improved wind energy dispatchability: Energy and economic assessment. Applied Energy, v. 147, p. 117-130, 2015. https://doi.org/10.1016/j.apenergy.2015.02.055

Hexu, S.; Zheng, L.; Aibing, C.; Yan, Z.; Chunxiao, M. Current status and development trend of hydrogen production technology by wind power. Transactions of China Electrotechnical Society, v. 34, no.19, p.4071-4083, 2019. https://doi.org/ $10.1177 / 0144598718787294$

Huang, Y. S.; Liu, S. J. Chinese green hydrogen production potential development: A provincial case study. IEEE ACCESS, v. 8, p. 171968-171976, 2020. https://doi.org/ 10.1109/access.2020.3024540

Ishaq, H.; Dincer, I. A comparative evaluation of OTEC, solar and wind energy based systems for clean hydrogen production. Journal of Cleaner Production, v. 246, 118736, 2019. https://doi.org/10.1016/j.jclepro.2019.118736

Ishaq, H.; Dincer, I.; Naterer, G. F. Performance investigation of an integrated wind energy system for co-generation of power and hydrogen. International Journal of Hydrogen Energy, v. 43, no. 19, p. 9153-9164, 2018. https://doi.org/10.1016/j.ijhydene.2018. 03.139

Ishaq, H.; Dincer, I. Dynamic analysis of a new solar-wind energy-based cascaded system for hydrogen to ammonia. International Journal of Hydrogen Energy, v. 45, no. 38, p. 18895-18911, 2020. https://doi.org/10.1016/j.ijhydene.2020.04.149

Rev. Bras. Gest. Amb. Sustent., 2021, vol. 8, n. 20, p. 1295-1313. 
Jahangiri, M.; Nematollahi, O.; Haghani, A.; Raiesi, H. A.; Alidadi Shamsabadi, A. An optimization of energy cost of clean hybrid solar-wind power plants in Iran. International Journal of Green Energy, v. 16, no. 15, p.1-14, 2019. https://doi.org/10.1080/ 15435075.2019.1671415

Kaldellis, J. K.; Kavadias, K.; Zafirakis, D. The role of hydrogen-based energy storage in the support of large-scale wind energy integration in island grids. International Journal of Sustainable Energy, v. 34, no. 3/4, p. 188-201, 2013. https://doi.org/10.1080/14786451. 2013.846342

Kameyama, H.; Yoshizaki, K.; Yasuda, I. Carbon capture and recycle by integration of CCS and green hydrogen. Energy Procedia, v. 4, p. 2669-2676, 2011. https://doi.org/ 10.1016/j.egypro.2011.02.167

Khaitan, S. K.; Raju, M.; McCalley, J. D. Design of a novel and efficient hydrogen compressor for wind energybased storage systems. International Journal of Hydrogen Energy, v. 40, no. 3, p. 1379-1387, 2015. https://doi.org/10.1016/j.ijhydene.2014.11.066

Kılkış, B. Exergetic comparison of wind energy storage with ice making cycle versus minihydrogen economy cycle in off-grid district cooling. International Journal of Hydrogen Energy, v. 42, no. 28, p.17571-17582, 2017. https://doi.org/10.1016/j.ijhydene.2017. 03.105

Kodicherla, S. P. K.; Kan, C.; Nanduri, P. M. B. R. K. Likelihood of wind energy assisted hydrogen production in three selected stations of Fiji Islands. International Journal of Ambient Energy, v. 41, no. 7, p. 1-10, 2018. https://doi.org/10.1080/01430750.2018. 1492444

Koroneos, C.; Katopodi, E. Maximization of wind energy penetration with the use of $\mathrm{H}_{2}$ production: An exergy approach. Renewable and Sustainable Energy Reviews, v. 15, no. 1, p. 648-656, 2011. https://doi.org/10.1016/j.rser.2010.06.022

Kudria, S.; Ivanchenko, I.; Tuchynskyi, B.; Petrenko, K.; Karmazin, O.; Riepkin, O. Resource potential for wind-hydrogen power in Ukraine. International Journal of Hydrogen Energy, v. 46, no. 1, p. 157-168, 2020. https://doi.org/10.1016/j.ijhydene.2020.09.211

Lee, J.-Y.; An, S.; Cha, K.; Hur, T. Life cycle environmental and economic analyses of a hydrogen station with wind energy. International Journal of Hydrogen Energy, v. 35, no. 6, p. 2213-2225, 2010. https://doi.org/10.1016/j.ijhydene.2009.12.082

Lepszy, S.; Chmielniak, T.; Monka, P. Storage system for electricity obtained from wind power plants using underground hydrogen reservoir. Journal of Power Technologies, v. 97, no. 1, p. 61-68, 2017.

Li, Z.; Guo, P.; Han, R.; Sun, H. Current status and development trend of wind power generation-based hydrogen production technology. Energy Exploration \& Exploitation, v. 37, no. 1, 014459871878729, 2018. https://doi.org/10.1177/0144598718787294

Martín, M. Methodology for solar and wind energy chemical storage facilities design under uncertainty: Methanol production from $\mathrm{CO}_{2}$ and hydrogen. Computers \& Chemical Engineering, v. 92, p. 43-54, 2016. https://doi.org/10.1016/j.compchemeng.2016.05.001

Martín, M.; Grossmann, I. E. Optimal integration of a self sustained algae based facility with solar and/or wind energy. Journal of Cleaner Production, v. 145, p. 336-347, 2017. https://doi.org/10.1016/j.jclepro.2017.01.051

Mönnich, K.; Neumann, T.; Strack, M.; Braess, H.; Scheuerer, K. Large scale hydrogen production from wind energy in Patagonia, Argentina. Wind Engineering, v. 28, no. 5, p. 565-575, 2004. https://doi.org/10.1260/0309524043028028 
Mostafaeipour, A.; Dehshiri, S. J. H.; Dehshiri, S. S. H.; Jahangiri, M. Prioritization of potential locations for harnessing wind energy to produce hydrogen in Afghanistan. International Journal of Hydrogen Energy, v. 45, no. 58, p. 33169-33184, 2020. https://doi.org/ 10.1016/j.ijhydene.2020.09.135

Mostafaeipour, A.; Khayyami, M.; Sedaghat, A.; Mohammadi, K.; Shamshirband, S.; Sehati, M.-A.; Gorakifard, E. Evaluating the wind energy potential for hydrogen production: A case study. International Journal of Hydrogen Energy, v. 41, no. 15, p. 6200-6210, 2016. https://doi.org/10.1016/j.ijhydene.2016.03.038

Müller, S.; Groß, P.; Rauch, R.; Zweiler, R.; Aichernig, C.; Fuchs, M.; Hofbauer, H. Production of diesel from biomass and wind power: Energy storage by the use of the Fischer-Tropsch Process. Biomass Conversion and Biorefinery, v. 8, no. 2, p. 275-282, 2017. https://doi.org/10.1007/s13399-017-0287-1

Muyeen, S.M.; Takahashi, R.; Tamura, J. Wind power and hydrogen generation system with cooperatively controlled three-level NPC-VSC based energy capacitor. European Transactions on Electrical Power, v. 20, no. 8, p. 1071-1081, 2010. https://doi.org/ 10.1002/etep.385

Nadaleti, W. C.; Borges dos Santos, G.; Lourenço, V. A. The potential and economic viability of hydrogen production from the use of hydroelectric and wind farms surplus energy in Brazil: A national and pioneering analysis. International Journal of Hydrogen Energy, v. 45, p. 1373-1384, 2020. https://doi.org/10.1016/j.ijhydene.2019.08.199

Nadaleti, W. C.; Santos, G. B.; Lourenço, V. A. Integration of renewable energies using the surplus capacity of wind farms to generate $\mathrm{H}_{2}$ and electricity in Brazil and in the Rio Grande do Sul State: Energy planning and avoided emissions within a circular economy. International Journal of Hydrogen Energy, v. 45, no. 46, p. 24190-24202, 2020. https://doi.org/10.1016/j.ijhydene.2020.06.226

Nagasawa, K.; Davidson, F. T.; Lloyd, A. C.; Webber, M. E. Impacts of renewable hydrogen production from wind energy in electricity markets on potential hydrogen demand for light-duty vehicles. Applied Energy, v. 235, p.1001-1016, 2019. https://doi.org/ 10.1016/j.apenergy.2018.10.067

Nicita, A.; Maggio, G.; Andaloro, A. P. F.; Squadrito, G. Green hydrogen as feedstock: Financial analysis of a photovoltaic-powered electrolysis plant. International Journal of Hydrogen Energy, v. 45, no. 20, p.11395-11408, 2020. https://doi.org/10.1016/ j.ijhydene.2020.02.062

Olateju, B.; Kumar, A. Hydrogen production from wind energy in Western Canada for upgrading bitumen from oil sands. Energy, v. 36, no.11, p. 6326-6339, 2011. https://doi.org/10.1016/j.energy.2011.09.045

Olateju, B.; Monds, J.; Kumar, A. Large scale hydrogen production from wind energy for the upgrading of bitumen from oil sands. Applied Energy, v. 118, p. 48-56, 2014. https://doi.org/10.1016/j.apenergy.2013.12.013

Olmos, F.; Hennessy, B. P.; Manousiouthakis, I. V.; Somiari, I.; Manousiouthakis, V. I. Thermodynamic feasibility analysis of a water-splitting thermochemical cycle based on sodium carbonate decomposition. International Journal of Hydrogen Energy, v. 44, p. 4041-4061, 2019. https://doi.org/10.1016/j.ijhydene.2018.11.153

Ostadi, M.; Paso, K. G.; Rodriguez-Fabia, S.; Oi, L. E.; Manenti, F.; Hillestad, M. Process integration of green hydrogen: Decarbonization of chemical industries. Energies, v. 13, 4859, 2020. https://doi.org/10.3390/en13184859 
Proost, J. Critical assessment of the production scale required for fossil parity of green electrolytic hydrogen. International Journal of Hydrogen Energy, v. 45, no. 35, p. 17067-17075, 2020. https://doi.org/10.1016/j.ijhydene.2020.04.259

Rabiee, A.; Keane, A.; Soroudi, A. Technical barriers for harnessing the green hydrogen: A power system perspective. Renewable Energy, v. 163, p.1580-1587, 2021. https://doi.org/10.1016/j.renene.2020.10.051

Ramos, V.; Iglesias, G. Wind power viability on a small island. International Journal of Green Energy, v. 11, no. 7 p. 741-760, 2014. https://doi.org/10.1080/15435075.2013. 823434

Realpe-Jiménez, A.; Orozco-Agamez, J.; Acevedo-Morantes, M. Wind power for hydrogen production using a spiral electrolyzer. International Journal of Applied Engineering Research, v. 10, p. 9175-9183, 2015.

Rezaei, M.; Mostafaeipour, A.; Qolipour, M.; Arabnia, H.-R. Hydrogen production using wind energy from sea water: A case study on Southern and Northern coasts of Iran. Energy \& $\begin{array}{llll}\text { Environment, } & \text { v. } 29, \quad \text { no. } 3, & \text { p. 333-357, 2018. https://doi.org/10.1177/ }\end{array}$ $0958305 X 17750052$

Rezaei, M.; Khozani, N. N.; Jafari, N. Wind energy utilization for hydrogen production in an underdeveloped country: An economic investigation. Renewable Energy, v. 147, no. 1, p. 1044-1057, 2019. https://doi.org/10.1016/j.renene.2019.09.079

Safari, F.; Dincer, I. Assessment and optimization of an integrated wind power system for hydrogen and methane production. Energy Conversion and Management, v. 177, p. 693-703, 2018. https://doi.org/10.1016/j.enconman.2018.09.071

Sarrias-Mena, R.; Fernández-Ramírez, L. M.; García-Vázquez, C. A.; Jurado, F. Electrolyzer models for hydrogen production from wind energy systems. International Journal of Hydrogen Energy, v. 40, no. 7, p. 2927-2938, 2015. https://doi.org/10.1016/j.ijhydene. 2014.12.125

Schenk, N. J.; Moll, H. C.; Potting, J.; Benders, R. M. J. Wind energy, electricity, and hydrogen in The Netherlands. Energy, v. 32, no. 10, p. 1960-1971, 2007. https://doi.org/10.1016/ j.energy.2007.02.002

Sherif, S. A.; Barbir, F.; Veziroglu, T. N. Wind energy and the hydrogen economy-review of the technology. Solar Energy, v. 78, no. 5, p.647-660, 2005. https://doi.org/10.1016/ j.solener.2005.01.002

Sheth, J. P.; Grewal, G. S.; Srinet, V.; Govindan, T. P. Wind hydrogen based distributed energy system for rural India. Water and Energy International, v. 68, no. 2, p. 42-45, 2011.

Shi, S. Y.; Cheng, F.; Nayel, M. Discuss hydrogen production in Jiangsu Province using nongrid-connected offshore wind power. Applied Mechanics and Materials, v. 291/294, p. 2102-2108, 2013. https://doi.org/10.4028/www.scientific.net/AMM.291-294.2102

Shishido, S.; Takahashi, R.; Murata, T.; Tamura, J.; Sugimasa, M.; Komura, A.; Futami, M.; Ichinose, M.; Ide, K. Stabilization of wind energy conversion system with hydrogen generator by using EDLC energy storage system. Electrical Engineering in Japan, v. 168, no. 3, p. 10-18, 2009. https://doi.org/10.1541/ieejpes.128.17

Silva, E. P.; Marin Neto, A. J.; Ferreira, P. F. P.; Camargo, J. C.; Apolinário, F. R.; Pinto, C. S. Analysis of hydrogen production from combined photovoltaics, wind energy and secondary hydroelectricity supply in Brazil. Solar Energy, v. 78, no. 5, p. 670-677, 2005. https://doi.org/10.1016/j.solener.2004.10.011 
Troncoso, E.; Newborough, M. Electrolysers for mitigating wind curtailment and producing "green" merchant hydrogen. International Journal of Hydrogen Energy, v. 36, no. 1, p. 120-134, 2011. https://doi.org/10.1016/j.ijhydene.2010.10.047

Vega, R.; Ramos A.; Conde, E.; Reina, P. Pre-feasibility study of hybrid wind power- $\mathrm{H}_{2}$ system connected to electrical grid. IEEE Latin America Transactions, v. 9, no. 5, p. 800807, 2011. https://doi.org/10.1109/tla.2011.6030992

Wang, Z.; Wang, H.; Ji, S.; Wang, X.; Pollet, B. G.; Wang, R. Multidimensional regulation of $\mathrm{Ni}_{3} \mathrm{~S}_{2} \mathrm{Co}(\mathrm{OH})_{2}$ catalyst with high performance for wind energy electrolytic water. Journal of Power Sources, v. 446, 227348, 2020. https://doi.org/10.1016/j.jpowsour.2019. 227348

Yang, W.-J.; Aydin, O. Wind energy-hydrogen storage hybrid power generation. International Journal of Energy Research, v. 25, no. 5, p. 449-463, 2001. https://doi.org/10.1002/er.696

Yang, T. C. Initial study of using rechargeable batteries in wind power generation with variable speed induction generators. IET Renewable Power Generation, v. 2, no. 2, p. 89-101, 2008. https://doi.org/10.1049/iet-rpg:20070008

Yumurtac, Z.; Toprak, K. An economic analysis of hydrogen production using wind power. International Journal of Renewable Energy Research, v. 1, p. 11-17, 2008.

Zhang, G.; Wan, X. A wind-hydrogen energy storage system model for massive wind energy curtailment. International Journal of Hydrogen Energy, v. 39, no. 3, p. 1243-1252, 2014. https://doi.org/10.1016/j.ijhydene.2013.11.003

Zhao, G.; Nielsen, E. R.; Troncoso, E.; Hyde, K.; Romeo, J. S.; Diderich, M. Life cycle cost analysis: A case study of hydrogen energy application on the Orkney Islands. International Journal of Hydrogen Energy, v. 44, no. 19, p.9517-9528, 2018. https://doi.org/10.1016/j.ijhydene.2018.08.015

Zolezzi, J. M.; Garay, A.; Reveco, M. Large scale hydrogen production from wind energy in the Magallanes Area for consumption in the central zone of Chile. Journal of Power Sources, v. 195, no. 24, p. 8236-8243, 2010. https://doi.org/10.1016/j.jpowsour. 2009.12.060

License information: This is an open-access article distributed under the terms of the Creative Commons Attribution License, which permits unrestricted use, distribution, and reproduction in any medium, provided the original work is properly cited. 